\title{
KEARIFAN LOKAL TAHLILAN-YASINAN DALAM DUA PERSPEKTIF MENURUT MUHAMMADIYAH
}

\author{
Khairani Faizah \\ Jurusan Pekerjaan Sosial Program Pascasarjana \\ Universitas Islam Negeri Sunan kalijaga Yogyakarta \\ khairanifaizah69@gmail.com
}

\begin{abstract}
Tahlilan or selamatan have been rooted and become a custom in the Javanese society. Beginning of the selamatan or tahlilan is derived from the ceremony of ancestors worship of the Nusantara who are Hindus and Buddhists. Indeed tahlilan-yasinan is a form of local wisdom from the worship ceremony. The ceremony as a form of respect for people who have released a world that is set at a time like the name of tahlilan-yasinan. In the perspective of Muhammadiyah, the innocent tahlilan-yasinan with the premise that human beings have reached the points that will only get the reward for their own practice. In addition, Muhammadiyah people as well as many who do tahlilan-yasinan ritual are received tahlian-yasinan as a form of cultural expression. Therefore, this paper conveys how Muhammadiyah deal with it in two perspectives and this paper is using qualitative method. Both views are based on the interpretation of the journey of the human spirit. The human spirit, writing apart from the body, will return to God. Whether the soul can accept the submissions or not, the fact that know the provisions of a spirit other than Allah swt. All human charity can not save itself from the punishment of hell and can not put it into heaven other than by the grace of Allah swt.
\end{abstract}

Keywords: Tahlilan, Bid'ah, Muhammadiyah

Abstrak. Ritual tahlilan atau selamatan kematian ini sudah mengakar dan menjadi budaya pada masyarakat Jawa yang sangat berpegang teguh pada adat istiadatnya. Awal mula dari acara Selamatan atau tahlilan tersebut berasal dari upacara peribadatan (selamatan) nenek moyang bangsa Nusantara yang mayoritasnya beragama Hindu dan Budha. Sejatinya tahlilan merupakan satu bentuk kearifan lokal dari upacara peribadatan. Upacara tersebut sebagai bentuk penghormatan dan mendo'akan orang yang telah meninggalkan dunia yang diselenggarakan pada waktu seperti halnya waktu tahlilan. Dalam perspektif Muhammadiyah, tahlilan bersifat bid'ah dengan dasar pemikiran bahwa manusia ketika ia telah meninggal hanya akan mendapatkan pahala atas perbuatan yang mereka kerjakan sendiri. Sedangkan dalam perspektif lain, orang Muhammadiyah, secara kultural, juga banyak yang melakukan ritual tahlilan-yasinan sebagai bentuk ekspresi budaya. Oleh karena itu, tulisan ini hendak membentangkan dua sudut pandang mengenai tahlilan-yasinan dalam perspektif Muhammadiyah. Kedua pandangan itu secara garis besar berkaitan dengan tafsir atas perjalanan ruh manusia. Ruh manusia, apabila terpisah dari jasad, akan kembali kepada Allah saw. Apakah ruh dapat menerima kiriman atau tidak, sebenarnya tiada yang mengetahui urusan ruh selain Allah swt. Semua amal manusia tidak dapat menyelamatkan dirinya dari siksa neraka dan tidak pula dapat memasukkannya ke dalam surga selain karena rahmat Allah swt.

Kata Kunci: Tahlilan, Bid'ah, Muhammadiyah 


\section{Pendahuluan}

Setiap daerah pasti menyimpan potensi kearifan lokal sebagai wujud dari khazanah intelektual yang diekspresikan melalui ritual budaya masing-masing. Salah satu dari potensi kearifan lokal itu adalah ritual budayaagama dan kegiatan tahlilan yang sudah melekat pada sebagian masyarakat muslim Jawa.

Ritual tahlilan atau selamatan kematian ini sudah mengakar dan menjadi budaya pada masyarakat Jawa yang sangat berpegang teguh pada adat istiadatnya. Tradisi selamatan kematian atau tahlilan ini didasarkan pada konsep ajaran-ajaran yang dikembangkan.

Awal mula dari acara Selamatan atau tahlilan tersebut berasal dari upacara peribadatan (selamatan) nenek moyang bangsa Nusantara yang mayoritasnya beragama Hindu dan Budha.

Acara tahlilan merupakan upacara ritual seremonial yang biasa dilakukan oleh keumuman masyarakat Indonesia untuk memperingati hari kematian. Secara bersama-sama, berkumpul sanak keluarga, handai taulan, beserta masyarakat sekitarnya, membaca beberapa ayat $\mathrm{Al}$ Qur'an, dzikir-dzikir, dan disertai do'a-do'a tertentu untuk dikirimkan kepada orang yang telah meninggal. Dikarenakan dari sekian materi bacaannya terdapat kalimat tahlil yang diulang-ulang, maka acara tersebut dikenal dengan istilah "Tahlilan".

Acara ini biasanya diselenggarakan setelah selesai proses penguburan, kemudian terus berlangsung setiap hari sampai hari ketujuh. Acara ini diselenggarakan kembali pada hari ke 40 dan ke 100 .

Untuk selanjutnya acara tersebut diadakan tiap tahun dari hari kematian, walaupun terkadang berbeda antara satu tempat dengan tempat lainnya. Tidak lepas pula dalam acara tersebut penjamuan yang disajikan pada tiap kali acara diselenggarakan. Bentuk jamuannya bisa beraneka rupa. Biasanya meliputi nasi kenduri beserta hidangan kuliner lain seperti ayam, telur, sambal tempe, dan lain-lain. Bentuk dan hidangan itu juga tidak harus sama tiap daerah karena masingmasing wilayah memiliki keunikan dan tradisi tertentu.

Model penyajian hidangan biasanya selalu variatif, tergantung adat yang berjalan di tempat tersebut. Namun, pada dasarnya menu hidangan lebih dari sekadarnya cenderung mirip menu hidangan yang berbau kemeriahan. Oleh karena itu, acara tersebut terkesan pesta kecilkecilan, memang demikianlah kenyataannya.

Acara tahlilan telah diselenggarakan berabad-abad sehingga tanpa disadari sudah menjadi kelaziman suatu masyarakat. Konsekuensinya, bila ada yang tidak menyelenggarakan acara tersebut berarti telah menyalahi adat dan akibatnya ia diasingkan dari masyarakat. Bahkan lebih jauh lagi acara tersebut telah membangun opini muatan hukum, yaitu sunnah untuk dikerjakan dan sebaliknya, bid'ah apabila ditinggalkan.

Jika ditinjau dalam sejarah Islam, maka acara ritual tahlilan tidak dijumpai pada masa Nabi Muhammad, masa para sahabatnya, para Tabi'in maupun Tabi'ut tabi'in. Bahkan acara tersebut tidak dikenal pula oleh para Imam-Imam Ahlus Sunnah seperti Al Imam Malik, Abu Hanifah, Asy Syafi'i, Ahmad, dan ulama lainnya yang semasa dengan mereka ataupun sesudah mereka.

Sejatinya tahlilan merupakan satu bentuk kearifan lokal dari upacara peribadatan nenek moyang bangsa Nusantara yang mayoritasnya beragama 
Hindu dan Budha. ${ }^{1}$ Upacara tersebut sebagai bentuk penghormatan dan mendo'akan orang yang telah meninggalkan dunia yang diselenggarakan pada waktu seperti halnya waktu tahlilan.

Namun, acara tahlilan secara praktis di lapangan berbeda dengan prosesi selamatan agama lain, yaitu dengan cara mengganti dzikir-dzikir dan do'a-do'a ala agama atau kepercayaan lain dengan bacaan dari Al Qur'an, maupun dzikir-dzikir dan do'a-do'a ala Islam menurut mereka. Berdasarkan tinjauan historis bisa diketahui bahwa sebenarnya acara tahlilan merupakan adopsi dan sinkretisasi dengan agama lain.

\section{Mencermati fenomena}

masyarakat Muslim yang beraneka ragam paham dan aliran menyisakan beberapa hal yang menarik dan penting untuk dikaji dan diteliti. Salah satu dari keanekaragaman paham dan aliran itu lalu menciptakan karakteristik ekspresi relegi dalam bentuk khazanah budayaagama. Dengan kata lain, bagaimana seorang atau kelompok (jemaah) mengekspresikan pengalaman religiusnya yang khas berbanding lurus dengan pola sinkretisasi tahlilan.

Simbol-simbol keberagamaan itu tidak hanya sebagai pemenuhan religiusnya saja, tetapi lebih dari itu, yaitu mampu membangun solidaritas sosial, bahkan bisa saja sebagai mediasi untuk kekuatan politik dan pembangunan bangsa. Dari keanekaragaman paham dan aliran secara organisatoris maka dalam masyarakat Islam Indonesia mengenal dua organisasi sosial keagamaan terbesar, yaitu Nahdlatul Ulama (NU) dan Persyarikatan Muhammadiyah, di samping masih banyak ormas Islam yang lain.

1 Farhan, Hamim. 2008. Ritualisasi Budaya-Agama Dan Fenomena Tahlilan-Yasinan Sebagai Upaya Pelestarian Potensi Kearifan Lokal
Sedangkan dilihat dari cara menjalankan syariat (experience of relegious) dan kulturnya masing-masing Tahlilan memiliki ciri dan cara yang khas berkaitan dengan hal-hal furu'iyah (aturan-aturan sunnah/penting yang bukan pokok). Simbol-simbol yang ada bisa dikenali secara sosiologis bagaimana seorang atau kelompok itu bisa disebut NU atau Muhammadiyah atau yang lainnya secara antropologisosial.

Akan tetapi, dalam pelaksanaan amalan baik berupa tahlilan ini kemudian menjadi fenomena sosial tersendiri karena keberadaan tahlilan ini telah menjadi sebuah tradisi yang membudaya dalam masyarakat Jawa, dengan memiliki bentuk yang khas seperti dalam acara tahlilan itu memiliki waktu-waktu tertentu yang dianggap perlu untuk mengadakan acara tersebut.

Begitu juga kenyataan Tahlilan ini adalah merupakan bentuk pengislaman oleh para Wali, dari tradisitradisi yang telah ditinggalkan oleh pengaruh budaya Hindu, Budha dan animisme. Di antara misi para Wali itu adalah sebagai media dan metode dakwah untuk mengenalkan Islam melalui tradisi-tradisi yang sudah ada. Sehubungan dengan hal itu, munculnya acara tahlilan-yasinan ini setidaknya ada kaitannya dengan ritus kematian pada awalnya. Hal tersebut juga dipengaruhi oleh adanya faktor dari luar dan juga dikuatkan atau didukung dari ajaran (faham pelaku) Islam sendiri.

Tulisan ini mendiskusikan dua perspektif mengenai Tahlilan-Yasinan dalam pandangan Muhammadiyah. Dua pandangan itu jelas membentuk suatu pola sikap di bawah institusi keagamaan Muhammadiyah yang secara formal menegasikan ritual yang telah mentradisi itu. Sekalipun penjelasan ini

Dan Penguatan Moral Masyarakat. Jurnal Logos Vol.5 No.2 Januari 2008. Fakultas Agama Islam Universitas Muhammadiyah Gresik. 
mendudukan dua sudut pandang dalam satu institusi, tulisan ini tidak bermaksud mengoposisikan. Oleh sebab itu, tulisan ini sekadar mengulas fenomena budaya dalam jalur akademik. Dengan demikian, beban ilmiah tentu merupakan fondasi krusial di dalam tulisan ini.

\section{Metode Penelitian, Kebaruan dan Orisinalitas Kajian}

Banyak tulisan atau kajian ilmiah yang memposisikan perspektif Muhhamdiyah sebagai pihak penentang tradisi tahlilan-yasinan. Hal itu mengandaikan bahwa Muhhamdiyah merupakan organisasi masyarakat Islam terbesar di Indonesia yang tegas menolak. Akan tetapi, seiring dengan perkembangan waktu dan dialektika keilmuan para kader, baik di bawah maupun di atas, mereka banyak yang berselisih pendapat mengenai tradisi tahlilan-yasinan.

Persilihan itu wajar karena persoalan perbedaan dalam melihat teks atau ayat selalu meniscayakan beragam tafsir. Aneka interpretasi itu kemudian membentuk pola sikap yang berlainan, meskipun di sana bukan menyiratkan pertentangan. Hal wajar mengenai perbedaan itu, sekalipun di bawah payung Muhammadiyah, menjadi tidak terelakan. Menurut pandangan umum ihwal sosio-kultural dan argeologi pengetahuan, perbedaan pendapat adalah hal wajar karena secara sederhana dapat dikatakan: berbeda kepala, berbeda pemikiran.

Tulisan ini tidak bersikap berat sebelah dengan mengajukan salah satu argumen mengenai keharaman atau kebidahan tradisi tahlilan-yasinan. Lebih dari persoalan oposisi biner, kajian ini menyampaikan dua pendapat mengenai suatu objek secara sistematis

2 Paton, Michael Quin. Qualitative Evaluationn and Research Methods. Newbuy Park: SAGE Pub, 1990. dan empiris. Oleh karena tulisan ini dimaksudkan sebagai buah karya akademik, tulisan ini sekadar mengulas bagaimana Muhammadiyah memandang tradisi tahlilan-yasinan secara formal di satu sisi dan bagaimana orang Muhammadiyah yang lain tetap menjalankan tradisi tersebut di sisi lain.

Dua pendapat itu kemudian ditelusuri bagaimana premis argumentasi dibentuk dan dinarasikan sebagai sebuah sikap tegas mengenai suatu objek. Dengan demikian, tulisan ini dilandasi oleh studi kualitatif berbasis eksplorasi pustaka dan beberapa observasi di lapangan guna tambahan data. ${ }^{2}$ Dari data yang ditemukan itu selanjutnya dianalisis dan diurai secara sistematis dan komprehensif supaya mendapatkan kesimpulan kajian. Walaupun demikian, tulisan ini tidak mewakili lembaga berwenang atau menegaskan suatu generalisasi atas pendapat yang ada. Tulisan ini cenderung melengkapi, kalau tidak dikatakan memperbarui, kajian ilmiah mengenai perbedaan pendapat mengenai tradisi yasinan-tahlilan melalui dan dalam perspektif Muhammadiyah.

\section{Teori Tahlilan-Yasinan dalam Kerangka Kearifan Lokal}

Peringatan selamatan bagi masyarakat Jawa berkaitan dengan kematian karena dilakukan pada bulan kedelapan hitungan tahun Hijriyah Sya'ban atau bulan Ruwah (sebutan orang Jawa). Kata Ruwah berasal dari bahasa Arab Arwah, yaitu bentuk jamak dari kata ruh. Selamatan bagi masyarakat Jawa biasanya dilakukan pada hari pertama, hari ketujuh, hari keempat puluh, sampai hari keseribu. Semua hitungan hari bagi mereka memiliki arti yang penting ${ }^{3}$.

3 Wijaya, Saksono. 1995. Mengislamkan Tanah Jawa: Telaah Atas Metode Dakwah Wali Songgo. Mizan, Cetakan II, Bandung 
Upacara tahlilan untuk masyarakat luas telah menjadi budaya yang mapan (devinitif) atau prevalensi (kelaziman/kemestian) sehingga berimplikasi klaim bahwa, jika ada orang mati dan tidak ditahlili diibaratkan seperti kematian binatang. "Wong moti yen ora ditahlili koyo matine kebo utowo kucing", klaim seperti itu sering terdengar dari lisan pengamal dan penghayat tahlilan ketika mengomentari ada peristiwa kematian dari warga shahibul musibah yang tidak menyelenggarakan perjamuan tahlilan.

Implikasi selanjutnya, keluarga almarhum yang tidak menyelenggarakan upacara tahlilan tidak disebut sebagai 'ahlu sunnah waljamaah' dan sering didiskriminasikan dalam berbagai kerukunan sosial, jika keluarga almarhum tersebut merupakan warga minoritas di kampungnya.

Dilihat dari partisipan pelaksanaan tahlilan, ritus ini dapat dibagi menjadi tahlilan biasa dan tahlil kubra. Dalam tahlilan kubra melibatkan massa yang banyak (kolosal) dan dihadiri sejumlah kiyai besar dari berbagai kota, dilaksanakan di alunalun, atau di suatu kampus pondok pesantren besar di kota atau di desa.

Tahlilan semacam inilah yang biasanya sarat dengan muatan-muatan lain: atas nama kepentingan bangsa keprihatinan nasib bangsa yang kurang menguntungkan, atau penggalangan politik praktis.

Dalam acara istighasahan, mujahadahan, pengajian akbar atau yang sejenisnya, unsur tahlilan hampir tidak pernah tertinggal, dan biasanya malah didahulukan dari pada acara yang lain.

4 Mufid, Achmad. 2007. Risalah Kematian. Yogyakarta: Total Media 2007.

5 Al-Albani, Nashiruddin. 1999.

Tuntunan Lengkap Mengurus Jenazah,
Bagi manusia, kematian adalah proses berpisahnya ruh dari badan seseorang. Dalam Al-Quran Allas Swt menjelaskan bahwa jika ajal seseorang sudah datang maka, tidak ada seorang pun yang dapat mengulurnya 4 .

Petunjuk Rasulullah Saw, dalam masalah penanganan jenazah adalah petunjuk dan bimbingan yang terbaik dan berbeda dengan petunjuk umatumat yang lainnya, meliputi perlakuan atau aturan yang dianut umat kebanyakan.

Bimbingan Rasulullah Saw, dalam hal mengurus jenazah, di dalamnya mencakup hal yang memperhatikan sang mayat, yang kelak bermanfaat baginya baik ketika berada didalam kubur maupun saat tiba hari Kiamat. Termasuk memberi tuntunan, yaitu bagaimana sebaiknya keluarga dan kerabat memperlakukan mayat.

Dengan demikian, petunjuk dan bimbingan Rasulullah saw dalam mengurus jenazah ini merupakan potret aturan yang paling sempurna bagi sang mayat, baik dalam mu"amalahnya secara vertikal maupun horizontal.

Aturan yang sangat sempurna dalam mempersiapkan seseorang yang telah meninggal untuk bertemu dengan Rabbnya dengan kondisi yang paling baik lagi afdhal. Bukan hanya itu, keluarga dan orang-orang terdekat sang mayat pun disiapkan sebagai barisan orang-orang yang memuji Allah Swt dan memintakan ampunan serta rahmatNyabagi yang meninggal ${ }^{5}$.

Dalam hal ini Muhammadiyah berpendapat bahwa merupakan kewajiban masyarakat, artinya wajib kifayah bagi masyarakat untuk memandikan jenazah, mengkafani, menshalatkan, dan menguburkan, dalam pada itu menjadi kewajiban pula bagi

Penerjamah: Abbas Muhammad Basalamah. Jakarta: Gema Insan Pres. 
anggota masyarakat untuk membantu keluarga yang dapat musibah khususnya kematian keluarganya, jangan sampai menambah kesusahan keluarga yangsedang berkabung ${ }^{6}$.

Menurut Auguste Comte, konsensus terhadap kepercayaankepercayaan serta pandanganpandangan dasar selalu merupakan dasar utama untuk solidaritas dalam masyarakat. Tidak mengherankan kalau agama dilihat sebagai sumber utama solidaritas sosial dan konsensus.

Selain itu, kepercayaan agama mendorong individu untuk berdisiplin dalam mencapai tujuan yang mengatasi kepentingan individu dan meningkatkan perkembangan ikatan emosional yang mempersatukan individu dalam keteraturan sosial. Ikatan emosional itu didukung oleh kepercayaan bersama dan partisipasi bersama dalam kegiatankegiatan pemujaan? ${ }^{7}$.

Hal ini mengisaratkan manfaat tahlilan-yasinan diyakini sebagian masyarakat sebagai media untuk menyambung budaya kekerabatan (silaturahmi) dan kerukunan antarwarga.

Berpijak dari teori di atas menunjukkan bahwa fenomena tahlilan yang begitu luas pemaknaannya dari mulai awal muncul yang tidak bisa dipisahkan dengan adanya ritus kematian. Sebagai fenomena agama, sebagai tradisi relasi jamaah, sampai pada pembentuk integrasi sosial politik. Sedangkan sehubungan dengan masalah kematian, dari jaman primitif sampai sekarang senantiasa ditandai oleh suatu ritual.

6 Asjmuni, Abdurrahman Dkk. 2004. Fatwa-Fatwa Tarjih: Tanya Jawab Agama 3. Yogyakarta: Suara Muhammadiyah.

7 Johnson. 1994. Teori-Teori Sosiologi: Klasik dan Modern. Diindonesiakan Oleh Robert M.Z. Lawang, Gramedia, Jilid I,II, Jakarta.
Robertson Smith berpendapat bahwa ritus dapat memperkuat ikatanikatan sosial tradisional diantara individu-individu ${ }^{8}$. Bahkan lebih dari itu, kegiatan tahlilan ini mampu menjadi kekuatan pemersatu dari beberapa elemen untuk mempertahankan kemerdekaan.

Sementara dalam pandangan lain, Simuh (2002) mengatakan, aktivitas tahlilan-yasinan ini juga sebagai solusi dan media keakraban pada masyarakat perkotaaan. ${ }^{9}$ Di mana masyarakat perkotaan yang cenderung individualistis dan sibuk dengan aktivitas rutin sebagai ciri masyarakat industrialis.

Esensi budaya pesantren dan Nahdliyin merupakan kesinambungan ideologis dari pendekatan-pendekatan dan kebijakan Walisongo dalam menyebarkan agama Islam di Jawa. Posisi Walisongo dalam kehidupan sosio-kultural dan religius di Jawa sangat memikat hingga dapat dikatakan bahwa Islam tidak akan pernah menjadi the religion of Java jika sufisme yang dikembangkan oleh Walisongo tidak mengakar dalam masyarakat. Islam yang dibawa oleh Walisongo datang ke Jawa dengan penuh kedamaian meskipun lamban, tetapi meyakinkan.

Fakta menunjukkan bahwa dengan jalan menoleransi tradisi lokal serta memodifikasinya ke dalam ajaran Islam dan tetap bersandar kepada prinsip-prinsip Islam, agama ini dipeluk oleh mayoritas penduduk Jawa. Sesungguhnya, upaya islamisasi yang dilakukan oleh Walisongo merupakan ekspresi Islam kultural. Proses yang panjang dan secara gradual ini berhasil

\footnotetext{
${ }^{8}$ Geertz, 1993. Kebudayaan dan Agama. Kanisius, Cetakan II, Yogyakarta.

${ }^{9}$ Simuh. "Interaksi Islam dalam Budaya Jawa" dalam Muhammadiyah dalam Kritik. Surakarta: Muhammaddiyah University Press, 2002.
} 
mewujudkan tatanan kehidupan masyarakat santri yang saling damai berdampingan, peaceful coexistence yang dalam filsafat Jawa dikenal dengan konsep kesatuan, stabilitas, keamanan, dan harmoni ${ }^{10}$.

\section{Kiprah Walisongo}

Sebagaimana penjelasan sebelumnya yang menyebutkan soal bagaimana tradisi tahlilan-yasinan sebagai bentuk peleburan nilai-nilai Islam di Nusantara yang sebelumnya kebanyakan penduduk memeluk agama Hindhu-Budha, peran Walisongo di sini perlu diulas kembali. Sebagai pihak yang berkontribusi besar terhadap "pengislaman" Nusantara, Walisongo mempunyai strategi tersendiri guna penyebaran nilai-nilai Islam secara kultural. Sedikit-banyak Walisongo turut memperkaya diskursus tahlilanyasinan di Nusantara. Oleh karena itu, berikut dijelaskan profil berikut peran apa yang dimainkan oleh Walisongo. ${ }^{11}$

1. Sunan Gunung Jati

Secara genealogis Sunan Gunung jati masih keturunan darah terhormat, baik dari keturunan ayah dan ibunya. Jika menilik sejarah, ibu Sunan Gunung jati merupakan putri Raja Pajajaran, sedangkan bapaknya masih satu garis dengan Nabi Muhammad. Dalam praktik dakwah di Nusantara Sunan Gunung Jati tidak sendiri karena selalu mengikuti musyawarah dengan para wali lain. Salah satu kontribusi Sunan Gunung Jati adalah pembangunan Masjid Demak. Metode dakwah yang dilakukannya di masyarakat adalah pendekatan kultural. 2. Sunan Muria

10 Mas'ud, Abdurrahman. 2004. Intelektual Pesantren Perhelatan Agama dan Tradisi. Yogyakarta: Lkis.

11 Rujukan tekstual diambil dari studi Lufaefi. 2018. Reaktualisasi Dakwah Wali Songo: Gerak Dakwah KH Said Aqil Siroj dalam Menebar Islam Rahmatal Lil Alamin. Jurnal Aqalam,
Nama lain Sunan Muria adalah Umar Said. Namun, di samping dua sebutan itu, Sunan Muria mempunyai nama asli, yaitu Raden Said atau Raden Prawoto. Secara genealogis Sunan Muria merupakan anak Sunan Kalijaga. Sebagaimana ayahnya, Sunan Muria menggunakan kesenian sebagai metode dakwah. Lebih praktik, Sunan Muria menggunakan wayang kulit dan gamelan sebagai sarana dakwah. Sasaran masyarakat yang Sunan Muria tembak adalah pedagang, rakyat jelata, masyarakat pedusunan, dan nelatan.

3. Sunan Drajat

Wali bernama asli Munat ini merupakan putra kedua Sunan Ampel. Sunan Drajat melakukan hijrah ke Lamongan usai belajar agama dari ayahnya. Di dusun Drajat, Lampongan, Sunan Drajat mendirikan sebuah pesantren. Pesantren itu lebih banyak didominasi para fakir dan anak yatim karena sepanjang hidupnya Sunan Drajat menyantuni kedua kelompok masyarakat tersebut. Lebih spesifik, Sunan Drajat mendasarkan penyebaran agama Islam dengan bersumber dari AlQur'an, Sunnah, Ijma', dan qiyas sebagaimana pendekatan Sunan Ampel. 4. Sunan Kudus

Nama kecil Sunan Kudus adalah Ja'far Siddiq. Sebagaimana namanya, Sunan Kudus tinggal di Kota Kudus. Ia merupakan putra Sunan Ngudung atau Undung. Sunan Kudus sangat dipercaya masyarakat sekitar sebagai tokoh untuk menyebarkan agama sekaligus memimpin pemerintahan. Oleh karena itu, penduduk setempat menjulukinya sebagai Al-Alim (orang yang memiliki pengetahuan dan ilmu yang luas). Tidak

\footnotetext{
Journal of Islam and Plurality. Vol. 3, No. 1, Juni 2018. Lufaefi juga mendasarkan tesisnya berdasarkan referensi Penjabaran tentang sedikit biografi Wali Songo lebih lengkap lihat: Purwadi, Jejak Para Wali dan Ziarah Spiritual, Jakarta: Kompas, 2006, h. 16.
} 
sekadar mengajarkan nilai-nilai Islam berdasarkan lisan semata, Sunan Kudus juga menggunakan tindakan langsung.

\section{Sunan Kalijaga}

Sewaktu kecil Sunan Kalijaga mempunyai nama panggilan, yaitu Jaka Said atau Raden Said. Secara genealogis Sunan Kalijaga merupakan putra pengusaha besar di Tuban. Ayahnya adalah Bupati Tuban yang mempunyai nama Raden Sahur Temenggung Wilatika. Kalau melihat namanya, nama Kalijaga berasal dari bahasa Arab, yakni Qadi Zaka yang mempunyai makna pelaksana dalam menegakan kesucian (pemimpin). Sunan Kalijaga dikenal luas sebagai wali yang menyebarkan nilainilai Islam melalui kesenian wayang. Hal itu dilakukan Sunan Kalijaga sebagai bentuk sinkretisme karena masyarakat sekitar masih memeluk agama Hindhu dan Budha.

\section{Sunan Bonang}

Panggilan lain Sunan Bonang adalah Raden Makdum Ibrahim. Sunan Bonang merupakan keturunan Sunan Ampel. Sunan Bonang, selain menyebarkan agama Islam, juga dikenal sebagai wali yang berperan besar dalam mendirikan kerajaan Islam Demak. Sekilas namanya mirip dengan salah satu alat musik Jawa, yakni bonang. Sunan Bonang adalah pencipta alat musik tersebut.

\section{Sunan Giri}

Nama asli Sunan Giri adalah Raden Paku. Selain itu, Sunan Giri juga dijuluki sebagai Muhammad 'Ainul Yaqin. Secara genalogis Sunan Giri merupakan anak dari Dewi Sekardadu dan Maulana Ishak. Selama hidup, Sunan Giri mendirikan dan mengajarkan ilmu Islam di sebuah pesantren di dekat Gunung Giri. Sunan Giri juga menyebarkan Islam dengan wayang kulit. Terobosannya, ketika membuat wayang kulit yang semula mirip manusia, Sunan Giri kemudian merekonstruksi bentuk visual lain yang tidak menyerupai manusia karena, menurut tafsirnya, menyerupai manusia tidak diperbolehkan dalam Islam.

8. Sunan Ampel

Nama asli Sunan Ampel adalah Raden Rahmat. Selama hidup Sunan Ampel tinggal di Ampel dan mendirikan pesantren di sana. Sunan Ampel merupakan salah satu wali yang tidak setuju terhadap sesajian dan selamatan yang sering dibuat oleh orang Jawa. Menurut cerita sejarah, Sunan Ampel menyebarkan agama Islam dengan cara mengajarkan dan membuat kipas anyaman (terbuat dari rotan). Kipas tersebut bukan kipas biasa karena mampu menyembuhkan orang sakit. Akan tetapi, ketika terdapat orang yang ingin sembuh melalui kipas Sunan Ampel, ia memberikan persetujuan dengan prasyarat harus bersyahadat agar masuk Islam.

\section{Sunan Maulana Malik Ibrahim}

Syekh bernama Maulana Malik Ibrahim ini biasa dikenal dan disebut sebagai Syeikh Maghribi. Sunan Maulana Malik Ibrahim mempunyai dua orang putra bernama Sunan Ampel dan Sayid Ali Murtadha (Raden Santri). Sunan Maulana Malik Ibrahim merupakan salah seorang wali yang tidak langsung mengajarkan apa itu Islam, tetapi melalui ajaran pemenuhan kebutuhan dasar manusia. Cara tersebut cenderung bersifat menggunakan akal atau rasio sehingga dapat diterima dengan mudah oleh manusia.

Gambaran besar eksistensi dan kontribusi sembilan wali yang berjuang menyebarkan nilai-nilai Islam itu menegaskan bahwa internalisasi Islam ke masyarakat kultural yang mempunyai latar belakang agama bukan Islam merupakan hal yang cukup kompleks. Hal itu dikarenakan sinkretisme tanpa metode dan cara penyebaran yang relevan maka tidak akan mencapai keutuhan komprehensif. Uraian mengenai Walisongo di atas membuktikan betapa tahlilan-yasinan 
merupakan cara alternatif dalam penyebaran Islam secara ramah dan kultural.

Proses sinkretisme nilai Islam dan budaya tahlilan-yasinan bisa dipandang sebagai proses Islamisme. Salah satu pokok Islamisme itu diuraikan Siti Mahmudah ke dalam tiga pemahaman Islamisme. Salah satunya adalah mengenai agama politik dan problematika politik.

"Dimana Islamisme itu berasal dari politisasi agama. Jika agama yang dipolitisasi ini hanyalah indikasi dari adanya perbedaan budaya, bisa disediakan ruang dengan mengatasnamakan

keanekaragaman."12

\section{Perspektif Muhammadiyah}

Muhammadiyah berpandangan bahwa yang disebut bid'ah adalah halhal yang baru dan diada-adakan dalam hal agama (ibadah) adalah haram, sesat dan tertolak.

Sedangkan di luar urusan agama (ibadah) dan terkait dengan mu'amalat duniawiyah, kultur/budaya/adat/'urf serta penemuan teknologi yang tidak diatur dalam ketentuan ibadah, maka termasuk al-ibahah (kebolehan), betapapun dalam fungsinya memberikan kemudahan dan dukungan terhadap pelaksanaan ibadah. Semua bentuk bid'ah dalam hal ibadah adalah sesat dan tertolak.

Muhammadiyah bekerja untuk tegaknya ibadah yang dituntunkan oleh Rasulullah saw tanpa tambahan dan perubahan dari manusia. Muhammadiyah bekerja untuk terlaksananya mu'amalat duniawiyat (pengolahan dunia dan pembinaan masyarakat) dengan berdasarkan ajaran agama serta menjadikan semua kegiatan

12 Mahmudah, Siti. 2018. Islamisme: Kemunculan dan Perkembangannya di dalam bidang ini sebagai ibadah kepada Allah swt.

Fatwa Majlis Tarjih Muhammadiyah, yang dilarang menurut Muhammadiyah dalam pelaksanaan tahlilan adalah upacaranya yang dikaitkan dengan tujuh hari kematian, atau empat puluh hari, atau seratus hari dan sebagainnya.

Apalagi upacara semacam itu harus mengeluarkan biaya besar, yang terkadang harus pinjam kepada tetangga atau saudaranya, sehingga terkesan tabzir (berbuat mubadzir).

Begitu juga dengan upacara atau tradisi lainnya seperti memberikan uang kepada pelayat yang datang, kepada orang yang ikut serta dalam shalat jenazah dan lain sebagainnya.

Seharusnya ketika ada yang meninggal dunia kita harus bertakziah atau melayat dan mendatangi keluarga yang terkena musibah kematian sambil membawa bantuan atau makanan seperlunya sebagai wujud bela sungkawa. Bukan datang untuk mengharapkan uang dan lain sebagainya.

Sedangkan menanggapi alasan diadakannya tradisi tersebut bertujuan sebagai sedekah yang pahalanya ditujukan kepada yang meninggal dunia. Majlis Tarjih Muhammadiyah dalam Fatwanya menyatakan bahwa seorang manusia itu tidak akan mendapatkan pahala dari Allah Swt, selain pahala dari apa yang telah diusahakannya sebelum dia meninggal dunia.

Oleh karena itu, dia tidak akan mendapatkan pahala apa-apa dari Allah Swt karena dia tidak lagi bisa beramalshaleh. Jika dicermati lebih mendalam, tahlilan yang beredar di tengah-tengah masyarakat luas ini terdapat unsur-unsur yang dianggap bid'ah yang dijelaskan sebagai berikut.

Indonesia. Jurnal Aqlam, Journal of Islam and Plurality. Vol. 3, No. 1, Juni 2018. 
1. Mengirim pahala

Makna mengirim adalah memberikan "sesuatu" kepada orang lain dengan menggunakan perantara orang lain, teman, kurir, atau tukang pos. Jika 'sesuatu' itu berwujud pahala sulitlah diketahui siapa yang menjadiperantara. Tidak ada teks apa pun dari Allah dan Rasululah yang menjelaskan tentang pengiriman pahala seperti itu. Esensi doa adalah meminta atau memohon. Kegiatan ini dilakukan karena yang bersangkutan tidak memiliki sesuatu lalu ingin memilikinya sementara ia tidak mempunyai alat tukar atau membeli untuk memilikinya.

Jadi ungkapan 'kirim pahala' sebenarnya tidak bermakna (Mystical language). Syariat formal memohonkan ampunan terhadap orang mati adalah dengan menyalatinya. Di dalam menyalati itu ada doa khusus ampunan untuk jenazah. An-Nawawi Bantani mengatakan bahwa mengirim pahala kepada orang yang telah meninggal adalah haram. Arsyad al-Banjari dan alMawa'iz mengatakan bahwa mengirim pahala untuk orang yang telah mati adalah bid'ah. Para ulama Mutaqaddimun memutlakkan bahwa pahala membaca Al-Qur'an itu tidak sampai pada jenazah. Tentunya pahala itu diberikan untuk yang membaca Jelasnya, seseorang itu tidak menanggung dosa dari orang lain, demikian juga pahala tidak akan sampai (kepada orang lain) kecuali apa yang telah dilakukan oleh dirinya sendiri.

Imam Syafi'i dan para pengikutnya beristinbat bahwa hadiah pahala dari bacaan itu tidak sampai kepada orang mati karena mereka (orang mati) itu bukanlah yang melakukannya. Rasulullah tidak menganjurkan dan tidak mendorong umatnya untuk melakukannya (hadiah pahala). Beliau tidak memberikan petunjuk dengan nash, tidak pula dapat dinukilkan satu orang pun dari para sahabat. Jadi, pengiriman pahala itu tak akan sampai kepada orang mati yang ditujunya karena tidak ada makhluk apa pun yang diutus oleh Allah untuk menyampaikan pahala. Mengirm hadiah pahala untuk orang yang sudah meninggal dunia tidak ada tuntunannya dari ayat-ayat Al-Qur'an maupun hadits Rasul. Muhammadiyah berpendapat bahwa ketika dalam suatu masalah tidak ada tuntunannya, maka mengacu pada sabda Rasulullah SAW hal tersebut dinyatakan bid'ah.

2.Wasilah (Perantara)

Di dalam pelaksanaan tahlian itu biasanya juga mengangkat ruh-ruh tertentu yang disebut wali. Wali itulah yang diyakini menyampaikan doa yang dipanjatkan kepada Allah. Di antara walli-wali perantara itu adalah: Rasulullah, syuhada' perang Badar, Syeikh Abdul Qadir al-Jaelani, SyeikhJunaid al-Baghdadi, Syeikh Naqshabandi, walisongo, dan lain-lain. Praktik ibadah semacam ini sama sekali tidak diajarkan oleh Rasulullah. Kitab tafsir apa pun menyebutkan bahwa perantara itu adalah amal sholeh, bukan ruh mediator.

Sebaliknya, Allah mengajarkan agar dalam berdoa itu langsung kepadaNya. Berdasarkan naskah resmi dalam Islam, yaitu al-Qur'an dan As-Sunah ashshahihoh al-muqbolah Allah tidak pernah mengangkat ajudan apa atau siapa pun yang menghantar doa kepadaNya. Dengan demikian, berdoa kepada Rasulullah pun tidak ada syariatnya. Apalagi selain beliau. Tugas Rasulullah kepada umat manusia hanya menyampaikan, dengan al-Qur'an dan sunnah beliau sendiri, tidak lebih dari itu. Ketika Beliauwafat selesailah tugasnya. Umat manusia tinggal hanya mengikuti dan melaksanakan tinggalan beliau, yaitu al-Qur'an dan as-Sunnah itu.

Banyak sekali pola ibadah ciptaan manusia yang dasarnya 
hanyalah mengikuti leluhur, mengikuti para tokoh-tokoh agama, iman buta, dalam kata lain dan (sangkaan belaka), atau sengaja mencampur aduk unsurunsur non Islam ke dalam Islam. Tahlilan di dalamnya dicampur dengan upacara memperingati mayat pada hari ke 7,40 , 100, mendhak Pisan, mendhak pindho, 1000, haul adalah campuran antara Islam dan Hindu. Mengirim pahala dalam tahlilan adalah campuran antara Islam, Hindu, dan impian orang-orang tertentu seperti al-Malibari. Tahlilan di dalamnya ada unsur hadiah pahala kepada jenazah adalah campuran antara Islam dan ciptaan muslim tertentu, entah siapa yang memulainya.

Namun, terdapat hipotesis menarik dari Greetz (1993) kalau peleburan budaya antara Hindhu dan Islam seperti tahlilan itu sebetulnya sebuah kewajaran dari proses akulturasi yang sering terjadi di dalam sistem sosial yang plural sebagaimana kondisi Indonesia pada masa lampau. ${ }^{13}$ Pengiriman pahala dalam tahlilan dengan menggunakan perantara ruhruh tertentu adalah campuran antara semangat Hindu, ciptaan umat Islam, dan ajaran Islam. Tahlilan boleh dan sangat utama, tetapi harus berpola yang $100 \%$ berdasar syariat.

\section{Makan-makan bersama}

Makan-makan setelah tahlilan dalam rangka memperingati orang mati ,emang secara sepintas pula, penyajian hidangan untuk para tamu merupakan perkara yang terpuji, bahkan dianjurkan sekali didalam agama Islam. Namun, manakala penyajian hidangan tersebut dilakukan oleh keluarga jenazah baik untuk sajian tamu undangan tahlilan ataupun yang lainnya, maka memiliki hukum tersendiri. Bukan hanya saja tidak pernah dicontohkan oleh Rasulullah shalallahu 'alaihi wasallam, bahkan perbuatan ini telah melanggar sunnah para sahabatnya radhiallahu 'anhum. Oleh karena itu, acara berkumpul di rumah keluarga jenazah dan penjamuan hidangan dari keluarga jenazah termasuk perbuatan yang dilarang oleh agama menurut pendapat para sahabat Rasulullah shalallahu 'alaihi wasallam dan para ulama salaf.

$$
\text { Malah yang semestinya, }
$$
disunnahkan bagi tetangga keluarga jenazah yang menghidangkan makanan untuk keluarga mayit, supaya meringankan beban yang mereka alami. Dengan demikian, berkumpul-kumpul ditempat ahli jenazah hukumnya adalah bid'ah dengan kesepakatan para Shahabat dan seluruh imam dan ulama' termasuk di dalamnya imam empat. Akan bertambah bid'ahnya apabila ahli mayit membuatkan makanan untuk para penta'ziyah. Akan lebih bertambah lagi bid'ahnya apabila di situ diadakan tahlilan pada hari pertama dan seterusnya. Perbuatan yang mulia dan terpuji menurut sunnah nabi SAW kaum kerabat /sanak famili dan para tetangga memberikan makanan untuk ahli mayit yang sekiranya dapatmengenyangkan mereka untuk mereka makan sehari semalam.

Manusia ketika ia telah meninggal hanya akan mendapatkan pahala atas perbuatan yang mereka kerjakan sendiri. Ruh manusia, apabila terpisah dari jasad akan kembali kepada Allah swt. Apakah ruh dapat menerima kiriman atau tidak, sebenarnya tiada yang mengetahui urusan ruh selain Allah Swt. Semua amal manusia tidak dapat menyelamatkan dirinya dari siksa neraka dan tidak pula dapat memasukkannya ke dalam surga, selain karena rahmat Allah swt. Oleh karena itu, yang ditunggu orang yang sudah meninggal adalah rahmat, ampunan, dan

13 Geertz, 1993. Kebudayaan dan Agama. Kanisius, Cetakan II, Yogyakarta. 
ridha Allah swt. Apabila hendak menyampaikan kiriman pahala amal orang yang sudah meninggal, perlu kita bertanya kepada diri kita masingmasing, apakah kita memiliki bukti bahwa amal kita pasti diterima Allah, lalu kita kirimkan kepada orang lain, sementara para nabi dan para shalihin apabila telah melakukan amal kebaikan, mereka tidak merasa sudah diterima.

\section{Toleransi Tahlilan-Yasinan: Cara Lain Kaum Muhammdiyah Perdusunan}

Penjelasan sebelumnya meneroka problematisasi praktik tahlilan-yasinan secara formal berdasarkan keputusan pimpinan pusat Muhammadiyah. Secara formal Muhammadiyah memang tidak membolehkan praktik kultural yang telah mengajar di tingkat daerah itu. Akan tetapi, dalam praktik sosial, selalu terdapat dua perspektif, yakni kelompok yang menerima keputusan secara terbuka dan kelompok yang dinamis karena menolak secara implisit.

Pandangan pertama jelas tidak melakukan praktik tahlilan-yasinan oleh karena pelarangan di tingkat pusat. Hal itu mengandaikan suatu dorongan patuh terhadap konvensi struktural Muhammdiyah. Bentuk penghormatan itu lazim terjadi karena betapapun Muhammadiyah adalah organisasi sosial-kemasyarakatan berbasis Islam yang cukup lama dan besar di Indonesia.

Salah seorang mantan Ketua Umum Pimpinan Pusat ke-12 Muhammadiyah, Amien Rais, lebih luas dan cair merespons persoalan perbedaan mengenai tahlilan-yasinan yang acap kali diperdebatkan di masyarakat. Sekalipun pernyataan itu bukan bentuk fatwa formal Muhammadiyah, namun pandangannya patut dikuip di sini. Amien menjelaskan lima sikap sebagai berikut. ${ }^{14}$

14 Datdut.com. 2017. Muhammadiyah Larang Tahlil, Ini 5 Komentar Amien Rais. Diakses pada 22 Juli 2018.
Pertama, tahli diuraikan di dalam tiga tingkatan antara lain tahli hati, tahlil lisan, dan tahlil perbuatan. Perluasan konsep tahlil tersebut diadopsi Amien dari tingkatan iman. Premis yang Amien gunakan kenapa membagi tiga tingkatan tahlil itu adalah tahlil sejatinya tindakan nyata dalam perbuatan kebaikan. Perbuatan itu bisa mencakup pembangunan pendidikan, kesehatan, ibadah, dan lain sebagainya. Dari kecenderungan itu Amien mengatakan kalau tahlil harus ditingkatkan secara maksimal dalam rangka amar ma'ruf nahi mungkar.

Kedua, tahlil dalam rangka mengatasi persoalan krisis sosial. Amien lebih praktik membumikan tahlil sebagai bentuk menghadapi krisis ekologi, pangan, kependudukan, dan energi. Pernyataan itu Amien sampaikan ketika menghadiri kesempatan tahlilan bersama pada Tablig Akbar Mukmatar Aisyiah ke-46 tahun 2010. Pada posisi tersebut Amien tidak bersikap pragmatis hanya mereduksi makna tahlil sebagai praktik syariat keagamaan, namun ia lebih mengejawantahkan dalam praktik berbangsa dan bernegara.

Ketiga, tahlil demi persatuan dan kesatuan umat. Argumen poin ketiga ini sangat relevan bagi sebuah bangsa, terutama Indonesia, yang sering menghadapi friksi horizontal. Oleh karena itu, persoalan itu mesti dihadapi melalui aktivitas tahlil agar pihak yang berselisih mampu rujuk dan solid kembali. Lebih konkret, Amien menjelaskan kalau tahlil sebagai ekspresi sosial di masyarakat telah mengakar melalui pembangunan masjid, tasyakuran, dan kegiatan-kegiatan lain di dusun. Tradisis semacam itu bernilai ibadah karena termasuk kontribusi konkret di lapangan. 
Keempat, lebih tegas, ketika menyampaikan poin-poin mengenai tahlilan-yasinan yang sering dipersoalkan warga Muhammadiyah, Amien mengatakan kalau tidak bersedia melakukan tahlil maka dipersilakan keluar dari organisasi (Muhammadiyah dan Aisyiah). Sikap tegas ini menjadi imperatif ketika yang menyampaikan pernyataan adalah seorang yang pernah memimpin Muhammdiyah. Akan tetapi, maksud Amien dalam pernyataan itu bukan sebatas tahlil lisan sebagaimana diketahui banyak orang, namun tahlil aksi nyata sebagai bentuk amal saleh di masyarakat.

Kelima, menguatkan empat poin sebelumnya, Amien menguatkan kembali pernyataan tahlil sebagai sikap dan perbuatan. Pada posisi itu Amien kembali mengulas rekam jejak pendiri Muhammadiyah, yaitu K.H. Ahmad Dahlan yang dari awal pendirian Muhammadiyah sudah bekerja keras untuk memperuangkan kemaslahatan masyarakat. Sikap itu ditegaskan kembali Amien dalam rangka pengamalan konsep tahlil dengan konsep perbuatan (arkan). Oleh karena itu, Amien mengimbau masyarakat Muhhamdiyah agar tidak sekadar fokus terhadap dirinya sendiri untuk masuk surga, sedangkan masyarakat di sekitarnya banyak terlilit problem ekonomi, sosial, budaya, maupun pendidikan.

Selain pernyataan personal Amien Rais di atas, pendangan orang Muhammadiyah terhadap yasin-tahlil di kalangan pedesaan juga beraneka ragam. Kalau asosiasi pembidahan melekat pada Muhammadiyah, namun di sebuah dusun di Watubelah, Tanjungsari, Gunungkidul bisa berbeda. Orang Muhammadiyah di salah desa di Yogyakarta bagian selatan itu cenderung menerima, bahkan lebih fleksibel. Salah satunya sebagaimana dinyatakan
Warsono, salah seorang warga Muhammadiyah di sana.

Menurut Warsono, mengikuti atau menyelenggarakan tradisi tahlil-yasisn merupakan bentuk ekspresi budaya yang telah turun-menurun. Sebagai warga Muhammadiyah, Warsono melihat tradisi tersebut sebagai proses bebrayan (bersama) yang menyiratkan nilai-nilai habluminannas di masyarakat. Meskipun orang Muhammadiyah yang lekat dengan pandangan negatif terhadap tahlil-yasin, Warsono memandangnya secara bijak. Oleh karena itu, ketika mengikuti tradisi tersebut di desa yang mayoritas masih mempertahankan tradisi tahlil-yasin, Warsono secara cair mengiktuinya tanpa takut mendapatkan stigma negatif.

Warsono di satu sisi juga mafhum kalau keputusan struktural soal pembidahan tahlil-yasin, namun di sisi lain tidak serta-merta mengikuti karena hal itu serupa fatwa (nasihat) semata. Sedangkan fatwa, bagi Warsono, bisa dikuti atau tidak karena betapapun ia tergantung kedaulatan atas pilihan masing-masing. Posisi untuk membolehkan tradisi tahlil-yasin itu menurut Warsono mesti dikembalikan lagi menurut pilihan individu. Oleh karena itu, sebagai orang Muhammadiyah, Warsono menganggap wajar kalau banyak warganya juga tidak sesuai nasihat Majelis Tarjih.

Warsono adalah salah satu contoh konkret di masyarakat betapa persoalan furuiyah seperti tradisi tahlil-yasin menghadapi respons beragam sesuai dengan keputusan masing-masing individu. Sekalipun mereka adalah warga Muhammadiyah yang secara formal dan generatif tidak membolehkan tradisi tersebut, namun pada praksisnya di lapangan justru berbeda pandangan.

Dengan demikian, sebagai sebuah organisasi kemasyarakatan yang 
memperjuangkan nilai-nilai Islam, Muhammadiyah secara baku tidak memperbolehkan tradisi yasin-tahlil. Namun, keputusan itu tidak dijelaskan secara konseptual kenapa dilarang. Oleh karena itu, hal demikian membawa pada kebebasan interpretasi atas keputusan pusat Muhammadiyah. Setidaknya, menurut penjelasan di dalam tulisan ini, pandangan mengenai pembidahan tradisi tahlil-yasin menemui dua jalur, yakni penerimaan dan penolakan.

Dikotomi ihwal penerimaan dan penolakan di Muhammadiyah yang diuraikan di dalam tulisan ini bukan simplikasi dan generalisasi atas wacana tradisi tahlil-yasin secara umum, namun ia sekadar eksplanasi akademik sebagai pembentangan fenomena budaya yang telah mengakar di Indonesia itu. Sebagai tulisan ilmiah, penjelasan di atas bermaksud objektif dan tidak mengambil sisi subjektif: menegaskan mana yang benar dan mana yang salah. Publik luas yang dapat menafsirkan kembali bagaimana seharusnya menempatkan tradisi tahlil-yasin sebagai pokok pembahasan di sini. Kemerdekaan pilihan tetap berada di tangan khalayak luas yang secara konstitusional dilindungi oleh negara.

\section{Kesimpulan}

Agar tetap murni bersyariat dalam bertahlilan, pelaksanaan tidak dicampur atau dilaksanakan dengan peringatan hari-hari kematian seseorang sebagaimana yang terjadi dalam Hinduisme. Kalau tetap dilaksanakan, itulah yang disebut mencampuradukkan antara ajaran Islam dan non ajaran Islam dalam pelaksanaan ibadah. Tahlilan tidak bisa disebut hanya sekadar budaya karena ada unsur-unsur keyakinan eskatologis di dalamnya, yaitu pengiriman pahala, yang dikirimi pahala menjadi banyak tabungan pahalanya, dan nantinya dihisab pahala amal shaleh mampu mengalahkan jumlah dan bobot amal buruk sehinggamenjadi selamat dari siksa kubur maupun akhirat. Pada hakikatnya orang yang sudah meninggal hanya membutuhkan doa, bukan kiriman pahala amal perbuatan yang diniatkan untuknya, jenazah masuk surga atau tidak tergantung amal perbuatannya sewaktu masih hidup.

Salah satu pandangan di atas adalah produk tafsir mengenai tradisi tahlil-yasin. Interpretasi lain juga dimungkinkan terjadi seperti pembolehan warga Muhammadiyah terhadap tahlil-yasin. Salah satu contoh yang membolehkan diambil dari studi kasus di dusun Watubelah, Tanjungsari, Gunungkidul. Selain itu, tokoh Muhammadiyah seperti Amien Rais, merekonstruksi secara luas makna tradisi tahlil sebagai ekspresi perjuangan sosial-kemasyarakatan.

\section{DAFTAR PUSTAKA}

Al-Albani, Nashiruddin. 1999. Tuntunan Lengkap Mengurus Jenazah, Penerjamah: Abbas Muhammad Basalamah. Jakarta: Gema Insan Pres.

Asjmuni, Abdurrahman dkk. 2004. Fatwa-Fatwa Tarjih: Tanya Jawab Agama Yogyakarta: Suara Muhammadiyah.

Datdut.com. 2017. Muhammadiyah Larang Tahlil, Ini 5 Komentar Amien Rais. Diakses pada 22 Juli 2018.

Farhan, Hamim. 2008. Ritualisasi Budaya-Agama Dan Fenomena Tahlilan-Yasinan Sebagai Upaya Pelestarian Potensi Kearifan Lokal Dan Penguatan Moral Masyarakat. Jurnal Logos Vol.5 No.2 Januari 2008. Fakultas 
Agama Islam Universitas Muhammadiyah Gresik.

Geertz, 1993. Kebudayaan dan Agama. Kanisius, Cetakan II, Yogyakarta.

Johnson. 1994. Teori-Teori Sosiologi: Klasik Dan Modern. Diindonesiakan Oleh Robert M.Z. Lawang, Gramedia, Jilid I,II, Jakarta.

Mahmudah, Siti. 2018. Islamisme: Kemunculan dan Perkembangannya di Indonesia. Jurnal Aqlam, Journal of Islam and Plurality. Vol. 3, No. 1, Juni 2018.

Mas'ud, Abdurrahman. 2004. Intelektual Pesantren Perhelatan Agama dan Tradisi. Yogyakarta: Lkis.

Mufid, Achmad. 2007. Risalah Kematian. Yogyakarta: Total Media 2007.

Paton, Michael Quin. Qualitative Evaluationn and Research Methods. Newbuy Park: SAGE Pub, 1990.

Purwadi, Jejak Para Wali dan Ziarah Spiritual, Jakarta: Kompas, 2006, h. 16.

Lufaefi. 2018. Reaktualisasi Dakwah Wali Songo: Gerak Dakwah KH Said Aqil Siroj dalam Menebar Islam Rahmatal Lil Alamin. Jurnal Aqalam, Journal of Islam and Plurality. Vol. 3, No. 1, Juni 2018.

Simuh. "Interaksi Islam dalam Budaya Jawa" dalam Muhammadiyah dalam Kritik. Surakarta: Muhammaddiyah University Press, 2002.

Wijaya, Saksono. 1995. Mengislamkan Tanah Jawa: Telaah Atas Metode Dakwah Wali Songgo. Mizan, Cetakan II, Bandung. 